\title{
可溶性ポリアニリンと電解コンデンサへの応用
}

\author{
吉澤 篤志 ${ }^{a}$, 武田 政幸 ${ }^{b}$, 大浦 靖a, 竹本 裕輔 $^{a}$, 直井 勝彦*a
}

\section{Low-Molecular-Weight Soluble Polyaniline for Electrolytic Capacitor}

\author{
Atsushi YOSHIZAWA ${ }^{\mathrm{a}}$, Masayuki TAKEDA ${ }^{\mathrm{b}}$, Yasushi OURA ${ }^{\mathrm{a}}$, \\ Yusuke TAKEMOTO ${ }^{\mathrm{a}}$, and Katsuhiko NAOI*a
}

\begin{abstract}
a 東京農工大学工学部応用化学科 ( $\bar{T}$ 184-8588 小金井市中町 2-24-26) Department of Applied Chemistry, Tokyo University of Agriculture and Technology (2-24-26, Naka-cho, Koganei, Tokyo, 184-8588 Japan)

b 三菱化学秼)筑波研究所 ( ical Corporation (8-3-1, Chuo, Ami-machi, Inashiki-gun, Ibaraki, 300-0397 Japan)
\end{abstract}

Received May 15, 1998 ; Accepted September 28, 1998

\begin{abstract}
Conducting polymers based on polyanilines with highly soluble and yet sustain relatively high conductivity were attempted to synthesize by either electrochemical or chemical oxidation from the solutions containing aniline monomers and traces of para-substituted anilines, namely $p$-toluidine or sulfanilic acid. The resulting polymers turned out to have low molecular weight electroactive polyanilines terminated by them in the polymerization process. The as-grown polymers which are at the doped state, show high solubility $\left(250 \mathrm{mg} \mathrm{ml}^{-1}\right)$ in $\mathrm{N}$. methylpyrrolidinone, while ordinary polyanilines particularly at the doped state scarcely soluble in NMP or any other solvents. Gel permeation chromatography indicated that the number average molecular weight of such polymers were obtained as 4,500 to 6,100 (vs. polystyrene standards) which should be the lowest among the relevant data so far reported. The conductivity of these polymers were found unexpectedly high $\left(10^{-1}\right.$ to $\left.10^{-3} \mathrm{~S} \mathrm{~cm} \mathrm{~cm}^{-1}\right)$ for other soluble polyanilines substituted with various functional groups (normally $10^{-5}$ to $10^{-7} \mathrm{~S} \mathrm{~cm}^{-1}$ ). By

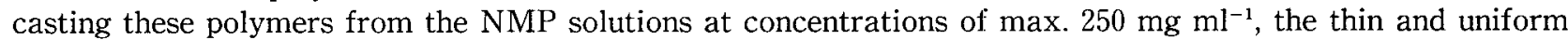
polymer films (typically $0.1 \mathrm{~mm}$ in thickness) were successfully formed on an anodized $\mathrm{Al}_{(}\left(\mathrm{Al}_{2} \mathrm{O}_{3}\right)$ foil to device Al electrolytic capacitors for further testing. The Al electrolytic capacitor displayed good / fair impedancefrequency characteristics in that they have relatively high resonance frequencies (in the order of $10^{7} \mathrm{~Hz}$ ) and showed low equivalent series resistance (min. $1.4 \Omega$ ).
\end{abstract}

Key Words : Polyaniline, Low-Moleclar-Weight, Aluminum, Solid Electrolytic Capacitor

\section{1 緒 言}

アルミニウムおよびタンタル電解コンデンサの陰極材料と して導電性高分子が注目を集めている。導電性高分子材料を 用いる理由の一つとして, 高い電気伝導率を有することが挙 げられる。例えば代表的な複素環式系導電性高分子であるポ リピロールの電気伝導率は，アニオンドーピングした酸化状

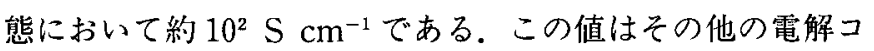
ンデンサ陰極材料である $\mathrm{TCNQ}$ 錯塩 $\left(10^{\circ} \mathrm{S} \mathrm{cm}^{-1}\right)$, 二酸化 マンガン $\left(10^{-1} \mathrm{~S} \mathrm{~cm}^{-1}\right)$, 有機電解液 $\left(10^{-2} \mathrm{~S} \mathrm{~cm}^{-1}\right)$ よりも 数桁高い.そのためポリピロールを陰極としたコンデンサは 優れた周波数特性を示し, さらに温度特性, 熱安定性にも優 れることが知られている ${ }^{1-7)}$.しかしポリピロールは不溶不融 で加工性に乏しいため，実際のコンデンサの作製においては 繁雑な工程が必要となる。例えば工藤らは酸化皮膜上に二酸 化マンガンなどの予備導電層を形成し，これを陽極として電 解重合を行うことによりポリピロール層を形成している年 もし各種溶媒に対する溶解性に優れた導電性高分子があれば, 溶液をキャストすることによって酸化皮膜上に高分子層を形 成できる。この層が高い導電性を示せば, 従来の多くの繁雑
なプロセスを省略した画期的な電解コンデンサの作製プロセ スとなりうる.

一方, 含へテロ原子共役系導電性高分子であるポリアニリ ンは酸抢よびアルカリ処理により同じ酸化状態でありながら 導電性のエメラルディン塩と絶縁性のエメラルディン塩基と 呼ばれるの二つの形態を取りうる興味深い導電性高分子であ る (Fig. 1) ${ }^{8}$. 電解重合や化学重合で初めに得られるのはエメ ラルディン塩であり，この状態では溶解性にそしい。 このエ メラルディン塩をアンモニア水などのアルカリ性溶液で脱ド ープすることによりエメラルディン塩基が得られ，溶解性が 向上する。例之ば化学重合や電解重合により得られたエメラ ルディン塩基（またはその一部）がジメチルスルホキシド (DMSO)，N-メチルピロリジノン (NMP)，テトラヒドロフ ラン（THF）などの溶媒に溶解すると報告されている ${ }^{9-11)}$. これらの例は重合法が異なるため生成したエメラルディン塩 基の分子量が異なっていると思われるが，分子量に関する記 載はない.一方，阿部らはペルオキソ二硫酸アンモニウムを 酸化戍として重合したエメラルディン塩基の分子量を GPC により測定しており $\left(M_{\mathrm{w}}=160,000\right)$ ，そのエメラルディン塩 

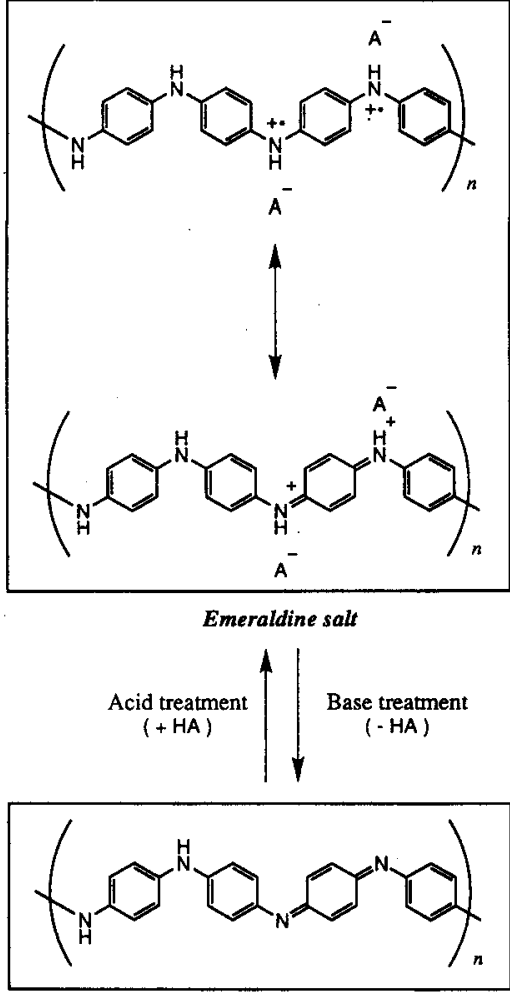

Emeraldine base

Fig. 1 Structures of polyaniline treated with acid (emeraldine salt) and with base (emeraldinebase).

基は NMP に対して $12 \mathrm{wt} \%$ 溶解度を有するが THF には 溶解しないことを報告している12)．エメラルディン塩基状態 のポリアニリンは絶縁性であり，成膜後にプロトン酸をドー ピングすると導電状態に戻ることが知られている。 しかし電 解コンデンサへの応用を考えた場合，強酸による処理は酸化 皮膜やアルミニウムなどの素地金属等を損傷する恐れがある ため好ましくない。

エメラルディン塩の状態で溶解性を向上させるには，アル キル基などの置換基をポリマー骨格に導入する方法が検討さ

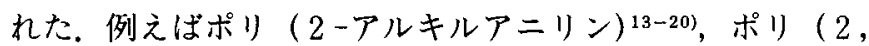

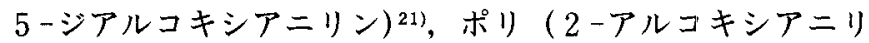
ン) ${ }^{22-26)}$, ポリ $\left(2,5\right.$-ジアルコキシアニリン) ${ }^{26)}$, ポリ $(\mathrm{N}$ アルキルアニリン)27-28)などが合成されている，また酸性置 換基であるスルホニル基 ${ }^{29-34)}$ やカルボキシル基 ${ }^{351}$, ホルホニ ル基 ${ }^{36)}$ を導入した自己ドープ型ポリアニリンが知られてい る.しかしこれらのポリ（置換アニリン）類は電気伝導率が 著しく低く，電解コンデンサの材料としては実用的でない． この電気伝導率の低下は大きな置換基によりポリアニリン鎖 の平面性が損なわれるためと考えられている.

そこでアニリンモノマーに対して置換基導入を行わず，電 気伝導率を損なわない程度に低分子量化できれば，溶解性の 向上したポリアニリンが得られると考えられる。我々は重合 時にポリアニリンの生長を停止する物質を少量添加すること により分子量を低下させ，溶解性の向上を検討した，本報で はこのような重合停止戍としてアニリンのアミノ基のパラ位 に置換基を有する化合物に着目し，置換基がメチル基である

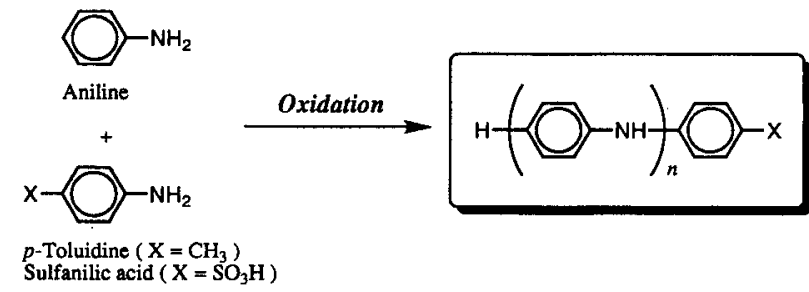

Fig. 2 Synthesis of low molecular weight polyaniline by polymerizing with $p$-substituted aniline, namely a) $p$. toluidine and b) sulfanilic acid, as a terminator.

p・トルイジンおよびスルホニル基であるスルファニル酸につ いて比較検討した（Fig. 2)。初めにパラ置換アニリン類の影 響について電気化学的な解析を行い，化学重合法により得ら れた低分子量ポリアニリンのキャラクタリゼーション，さら にキャスト法によるアルミ電解コンデンサの作製を試みた (Fig. 3).

\section{1 氜気化学的評価}

\section{2 実 験}

アニリンは市販の試薬（関東化学, 特級) を窒素気流下で 減圧蒸留により精製して使用した。その他は特級の試薬をそ のまま使用した。

サイクリックボルタンメトリーおよび in situ 電気化学水 晶振動子マイクロバランス $(\mathrm{EQCM})$ 測定は $0.1 \mathrm{M}(\mathrm{M} \equiv \mathrm{mol}$ ・ $\left.\mathrm{dm}^{-3}\right)$ のアニリンと $0.1 \sim 0.5 \mathrm{mM}$ のp.トルイジンまたは スルファニル酸を溶解した $0.1 \mathrm{M}$ 硫酸+0.4 M 硫酸ナトリ ウム水溶液中で行った(セイコーEG \& G, model 263 および QCA 917).AT-カット $9 \mathrm{MHz}$ 水晶振動子上にスパッタした 金 (面積 $0.2 \mathrm{~cm}^{2}$, 膜厚 $c a .300 \mathrm{~nm}$ ) を作用極に, 白金巻線を 対極に，銀一塩化銀電極を参照極として使用した。掃引範囲 $-0.2 \mathrm{~V} \sim+0.9 \mathrm{~V}$, 掃引速度 $100 \mathrm{mV} \mathrm{s}^{-1}$ にて 50 サイクル行 った，測定は全て室温，窒素霑囲気下で行った。

\section{2 ポリアニリンの化学重合とキャラクタリゼーション}

ポリアニリンの化学重合は過酸化水素一硫酸鉄 (II) を酸化 戍とする山本らの方法により行った ${ }^{37}$.アニリン $4.66 \mathrm{~g}(50.0$ $\mathrm{mmol}$ と $0.05-0.25 \mathrm{mmol}$ の p-トルイジンまたはスルファ 二ル酸を $0.5 \mathrm{M}$ 硫酸水溶液 $100 \mathrm{ml}$ に溶解し, 湯浴にて $30^{\circ} \mathrm{C}$ に保持した，続いて硫酸鉄 (II) 七水和物 $13.9 \mathrm{~g}$ (50.0 mmol)

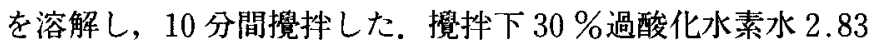
$\mathrm{g}(25.0 \mathrm{mmol})$ を 2 時間かけて滴下した。滴下終了後, $30^{\circ} \mathrm{C}$ でさらに 5 時間䚌汼した。青黑色の沈殿物をガラスフィルタ

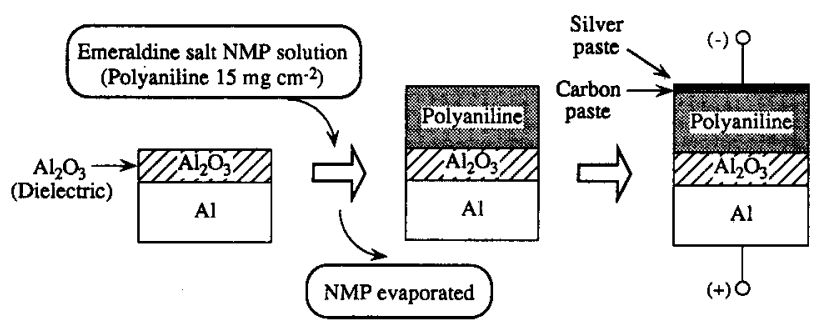

Fig. 3 Production process of aluminum electrolytic capacitor by use of casting procedure of the dissolved low molecular weight polyaniline. 
一で滤過し，水およびエ夕ノールで洗浄した後， $60^{\circ} \mathrm{C} て ゙$ 減圧 乾燥を行った。ポリアニリンの収率は 35〜38\%であった。得 られたポリアニリンの構造は FT-IR（パーキン・エルマー, System 2000）で $\mathrm{KBr}$ 錠剤法により確認した。

ポリアニリンの電気伝導率はプレスによりペレットを作製 し, 四短針法 (共和理研, 705 RM) により室温で測定した。 アンモニア水によりポリアニリンの脱ドープを行った後, ゲ ル浸透クロマトグラフィー (GPC；東ソー, HLC-8120)によ り平均分子量の測定を行った. 分析温度は $80^{\circ} \mathrm{C}$ ，カラムはポ リマー・ラボラトリーズ製 PL ゲル MIX-D を，溶離液は 10 $\mathrm{mM}$ 臭化リチウム $\mathrm{NMP}$ 溶液を，標準試料として単分散ポリ スチレンを用いた。

\section{3 アルミ電解コンデンサの作製とインピーダンスー周波 数特性の測定}

アルミニウムは純度 $99.99 \%$, 厚さ $0.1 \mathrm{~mm}$ のプレーン箔 （昭和アルミニウム）を $10 \times 10 \mathrm{~mm}^{2}$ に枝付き形状にカットし たものを用いた。アルミニウムの化成前処理としてアセトン で脱脂後, $0.1 \mathrm{M}$ 水酸化ナトリウム水溶液に室温で 10 分間浸 漬し, 水, アセトンで洗浄, 乾燥を行った。 アルミニウムの 化成処理は電流密度 $1 \mathrm{~mA} \mathrm{~cm} \mathrm{~cm}^{-2}$ の定電流電解により化成電 圧が $75 \mathrm{~V}$ に到達するまで行った，電解液は $0.1 \mathrm{M}$ アジピン 酸アンモニム (米山化学, コンデンサ用) 水溶液, 直流安定 化電源は菊水電子 PAD 500-2 L を使用した.

ポリアニリン層の形成はポリアニリン NMP 溶液のキャ ストにより行った，化成したアルミニウム試料上にポリアニ リン NMP 溶液を直接塗布後, 減圧下, $40^{\circ} \mathrm{C}$ での溶媒留去を 行った、キャストしたポリアニリンの総重量が約 $15 \mathrm{mg} \mathrm{cm}{ }^{-2}$ になるまでこの操作を繰り返した。 ポリアニリン層形成後, コロイダルカーボンおよび銀ペーストを塗布して院極リード を取り出し，アルミ電解コンデンサを作製した.

電解コンデンサのインピーダンスー周波数特性はインピー ダンス/ゲインーフェーズアナライザー（ヒューレット・パ ッカード，4194A）により測定した，測定結果をボード線困 に示し, 等価直列抵抗 (ESR) を求奻。

\section{3 結果および考察}

\section{1 バラ置換アニリン存在下での奄気化学的な解析}

重合浴中にパラ置換アニリン類を添加したとしても，どれ だけ有効な重合停止剤となるかは予測できない，そこでまず 電気化学的な測定により, パラ置換アニリン類がアニリンの 重合反応に及ばす影響を調べた。

パラ置換アニリン類としては置換基がメチル基である $p$ トルイジンとスルホニル基であるスルファニル酸を比較検討 した。これらの酸化電位をボルタンメトリーにより测定した 結果, アニリンの酸化電位は約 $+0.8 \mathrm{~V}$ (vs. $\mathrm{Ag} / \mathrm{AgCl}$ ) であ るのに対して, パラトルイジンは約 $+0.7 \mathrm{~V}$, スルファニル酸 は約+ $0.9 \mathrm{~V}$ であった。 パラ位の置換基によりそれぞれ電子 供与, 電子吸引の影響を受けるためと考えられる。 またパラ 置換アニリン単独では掃引を繰り返しても電気化学活性な膜 は得られなかった， p-トルイジンに関しては電解によりオル ト位でカップリングしたポリマーが得られたという報告があ るが，同定はなされていない38). a)
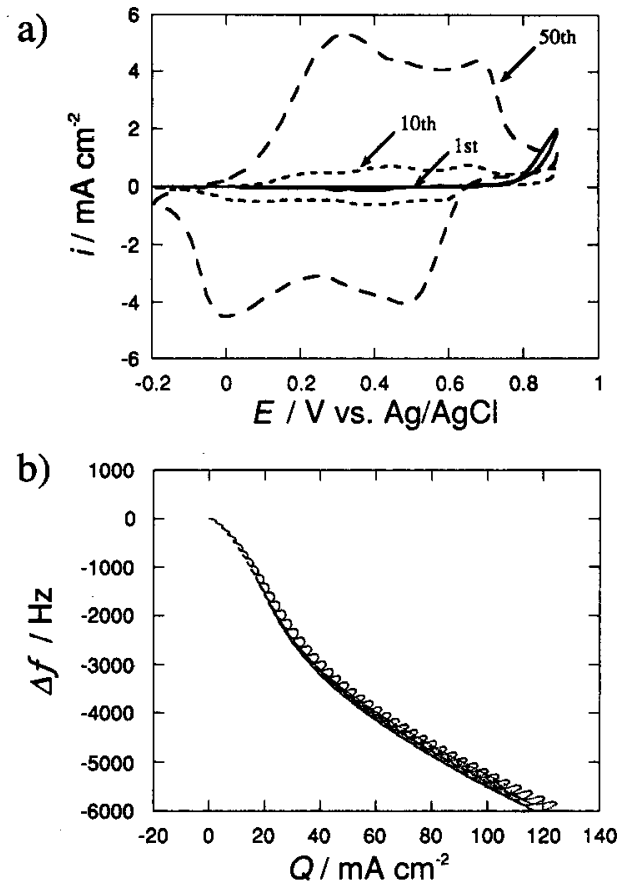

Fig. 4 a) Cyclic voltammograms and b) the plot of frequency shift $(\Delta f)$ versus charge density $(Q)$ during the electrodeposition in $0.1 \mathrm{M}$ aniline $+0.1 \mathrm{mM} p$-toluidine in $0.1 \mathrm{M} \mathrm{H}_{2} \mathrm{SO}_{4}-0.4 \mathrm{M} \mathrm{Na}_{2} \mathrm{SO}_{4}$ at $100 \mathrm{mV} \mathrm{s}^{-1}$.

Fig. 4 a にアニリンとp-トルイジンのモル比が 1000:1の サイクリックボルタモグラム $(\mathrm{CV})$ を, Fig. $4 \mathrm{~b}$ にその際 QCM により同時に測定した通電荷量 $(Q)$ に対する共振周波 数の変化 $(\Delta f)$ を示す. $\mathrm{CV}$ で現れた $+0.2 \mathrm{~V}$ および+0.6 V のレドックス対はポリアニリンの可逆な酸化遗元反応由来の ものであり ${ }^{39-40)}$, 電気化学活性なポリアニリンの成長が確認 された。このことは $\mathrm{QCM}$ の測定結果からもまた裏付けられ る。通電量が增加するにつれて共振周波数は振動を伴いなが ら直線的に低下した。これは電気化学量論的にポリアニリン の電析が進行していることを意味する．すなわち共振周波数 变化 $\Delta f$ は電極の質量变化 $\Delta m$ に比例すると考之ると,マク口 な低下はポリアニリンの電析を，それに伴う周波数の微小な 振動はドーパントアニオンである $\mathrm{SO}_{4}{ }^{2-}$ のドープ/脱ドー プに伴う質量変化を現している，p-トルイジンの代わりにス ルファニル酸を用いた場合も同様の傾向が認められた（Fig. $5 \mathrm{a}$ および Fig. 5 b).

Fig. 6 にアニリンとパラ置換アニリンのモル比を $1000: 0$ から $1000: 5$ まで変化させたときの電析効率 $\eta$ と第一酸化ピ 一ク電流 $i_{\mathrm{pa}}$ を示す.パラ置換アニリンが $p$-トルイジン, スル ファニル酸いずれの場合もその含有量の增加に伴い， $\eta$ およ び $i_{\mathrm{pa}}$ ともに減少する傾向を示した。これはパラ置換アニリ ンとの反応によって生長が停止した比較的低分子量で析出し にくいポリアニリンが生成しているためと考えられる。また 同一添加量でパラ置換アニリンの種類を比較すると, $p$-トル イシンの方がスルファニル酸より $\eta, i_{\mathrm{pa}}$ ともにより大きな滅 少を示した.これはp・トルイジンの酸化電位がより低いため にポリアニリンの生長末端と反応し易く，低分子量体を多く 生成したと考えられる。 
a)
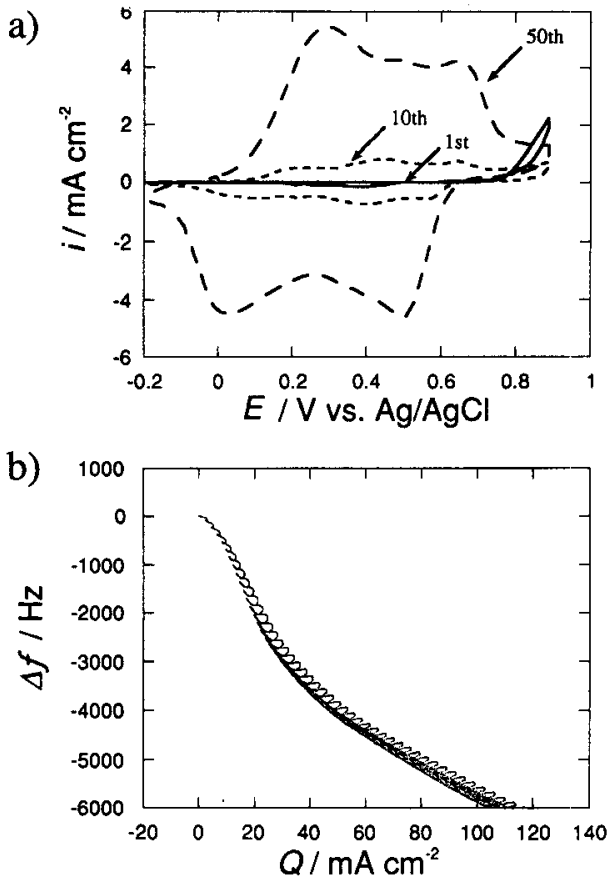

Fig. 5 a) Cyclic voltammograms and b) the plot of frequency shift $(\Delta f)$ versus charge density $(Q)$ during the electrodeposition in $0.1 \mathrm{M}$ aniline $+0.1 \mathrm{mM}$ sulfanilic acid in $0.1 \mathrm{M} \mathrm{H}_{2} \mathrm{SO}_{4}-0.4 \mathrm{M} \mathrm{Na}_{2} \mathrm{SO}_{4}$ at $100 \mathrm{mV} \mathrm{s}^{-1}$.

a)

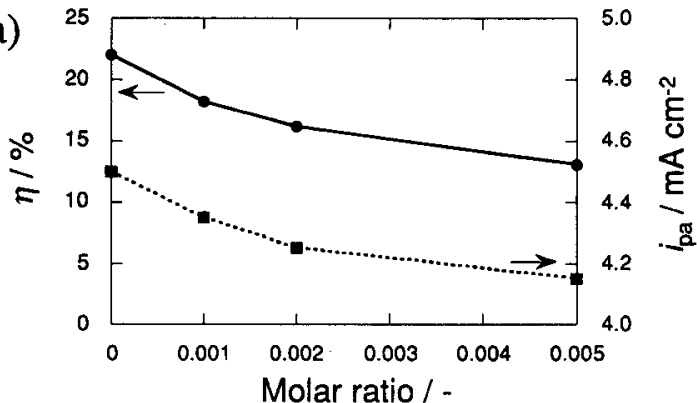

b)

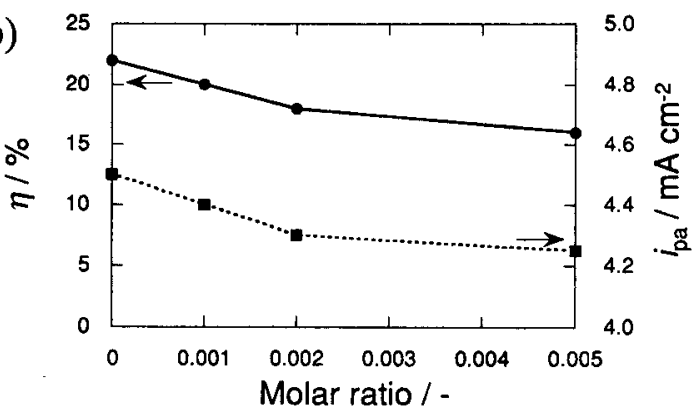

Fig. 6 Deposition efficiency $(\eta)$ and the anodic peak current $\left(i_{\mathrm{pa}}\right)$ at $+0.3 \mathrm{~V}$ (50th cycle) as a function of the molar ratio of a) $p$-toluidine / aniline and b) sulfanilic acid / aniline.

\section{2 ポリアニリンのキャラクタリゼーション}

Fig. 7 に化学重合により得られたポリアニリンの FT-IR スペクトルを示す．重合時のアニリンとパラ置換アニリンの モル比が 1000:0（Fig. 7 a) の場合と 1000:5 (Fig. 7b, 7c) の場合いずれもポリアニリンのベンゼノイド $\left(1500 \mathrm{~cm}^{-1}\right)$ お

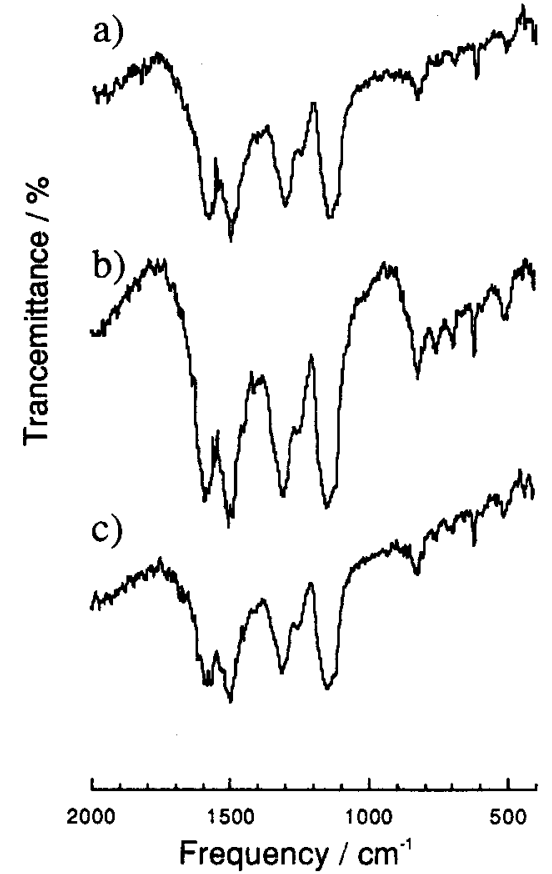

Fig. 7 FT-IR spectra for the polyanilines polymerized with a) no terminator, b) $p$-toluidine, and c) sulfanilic acid. The molar ratio of the $p$-substituted anilines / aniline $=0.005$.

よびキノイド構造 $\left(1590 \mathrm{~cm}^{-1}\right)$ に由来する吸収が観察され た。従ってパラ置換アニリンの存在下で重合したポリアニリ ンも，従来からよく知られた head-to-tail で結合した構造で あると考えられる。これら三種類のポリアニリンのスペクト ルを比較してみるとすると, p・トルイジンの存在下で合成さ れたポリアニリン Fig. $7 \mathrm{~b} に$ に抒いて $750 \mathrm{~cm}^{-1}$ おうび 695 $\mathrm{cm}^{-1}$ の吸収の強度が比較的大きいことがわかる. Feng らは アニリンの四量体および 16 量体を合成し，そのIR スペクト ルをポリマーを含めて比較している41).この報告によると,重 合度が大きくなるにつれてこの二つの IR 吸収強度が明らか に低下している。従って酸化電位が低く反応性に富んだ ルイジン添加系においては得られたポリアニリンは，より多 くの低分子量体を含んでいることが示唆される。

Fig. 8 にパラ置換アニリン存在下で化学重合により得られ たポリアニリンの電気伝導率 $\sigma$ とMPに対する溶解性を 示す.アニリンとパラ置換アニリンのモル比を $1000: 0$ から $1000: 5$ まで変化させた，パラ置換アニリンの増加に伴い， $\sigma$ は低下し，溶解性は約 1.7 倍に向上した，スルファニル酸を 用いた場合, 電気伝導染の低下が小さいにもかかわらず, 溶 解性の向上は $p$-トルイジンと同等であった。

Fig. 9 にGPCにより測定したFig. 8 と同じ試料の化学重 合ポリアニリンの数平均分子量 $M_{\mathrm{n}}$ および分子量分布の広が りを表す $M_{\mathrm{w}} / M_{\mathrm{n}}$ を示す. 数平均分子量はパラ置換厂ニリン を含まない通常の柔では $M_{\mathrm{n}}=6,600$ であるが，アニリンと パラ置換アニリンのモル比を $1000: 5$ まで増加させた場合, $p$-トルイジンの場合で $64 \%$ まで低下 $\left(M_{\mathrm{n}}=4,200\right)$, スルフ アニル酸の場合で $79 \%$ まで低下していた $\left(M_{\mathrm{n}}=5,200\right)$. $M_{\mathrm{w}} / M_{\mathrm{n}}$ は $p$-トルイジンでは顕著な变化は認められなかった が，スルファニル酸では 5.7 まで上昇した。これはスルファ 

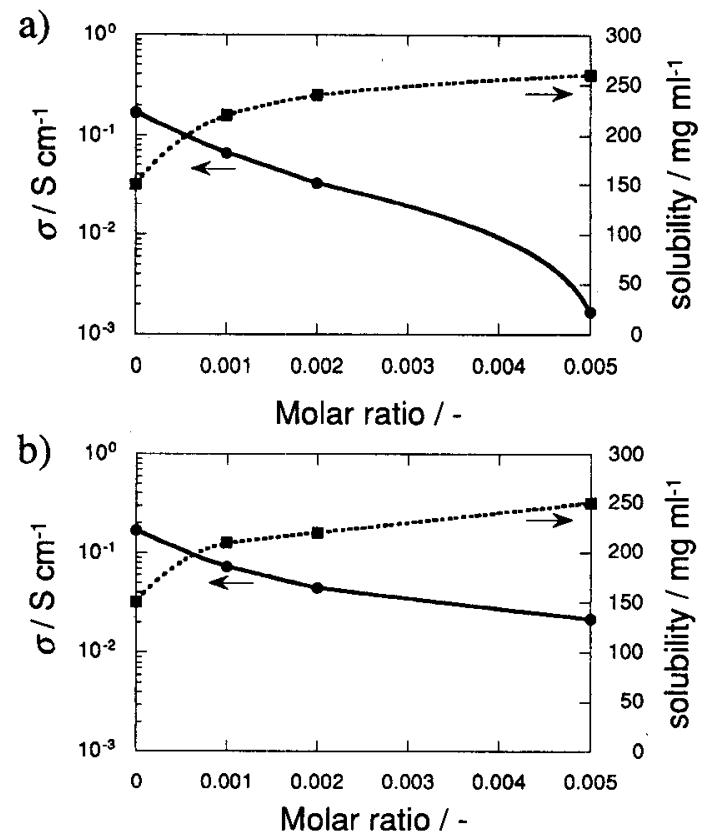

Fig. 8 Electrolytic conductivity $(\sigma)$ and the solubility of polyaniline in $1 \mathrm{ml}$ of $\mathrm{N}$-methylpyrrolid in one (NMP) as a function of the molar ratio of a) $p$-toluidine / aniline and b) sulfanilic acid/ aniline.

a)
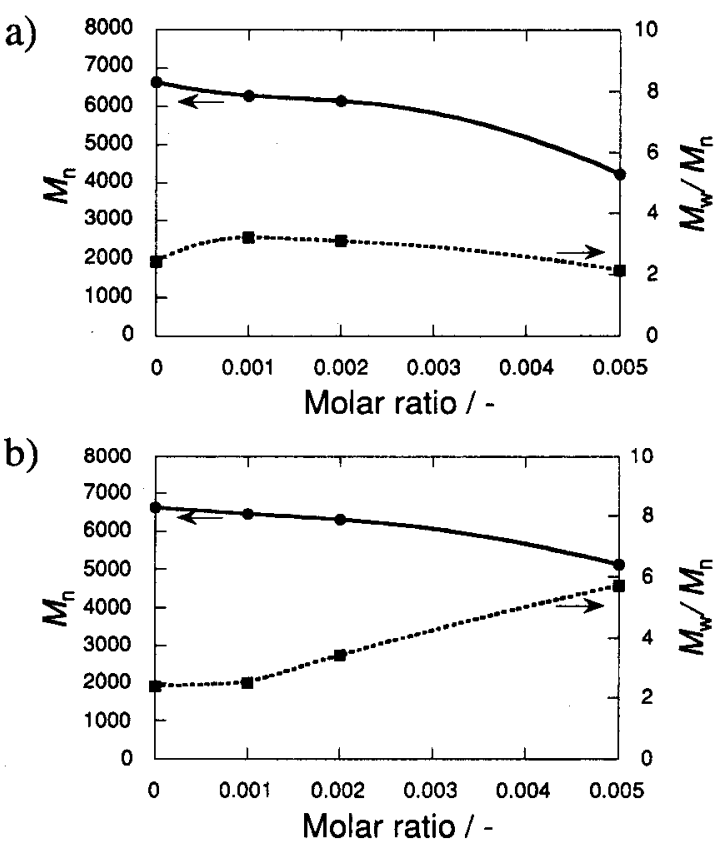

Fig. 9 Number average molecular weight $\left(M_{\mathrm{n}}\right)$ and dispersion $\left(M_{\mathrm{w}} / M_{\mathrm{n}}\right)$ of the polyaniline as a function of the molar ratio of a) $p$-toluidine / aniline and b) sulfanilic acid / aniline.

ニル酸存在下で生成したポリアニリンの方がより高分子量の ポリマーを含んでいるためであると考えられ，これが電気伝 導率の低下を抑制していると考えられる。

Fig. 10 にポリアニリン (エメラルディン塩)をキャストす ることにより作製したアルミ固体電解コンデンサのボード線 図を示した。ポリアニリン重合時のアニリンとパラ置換アニ リンのモル比は 1000:1である。パラ置換アニリンを含まず
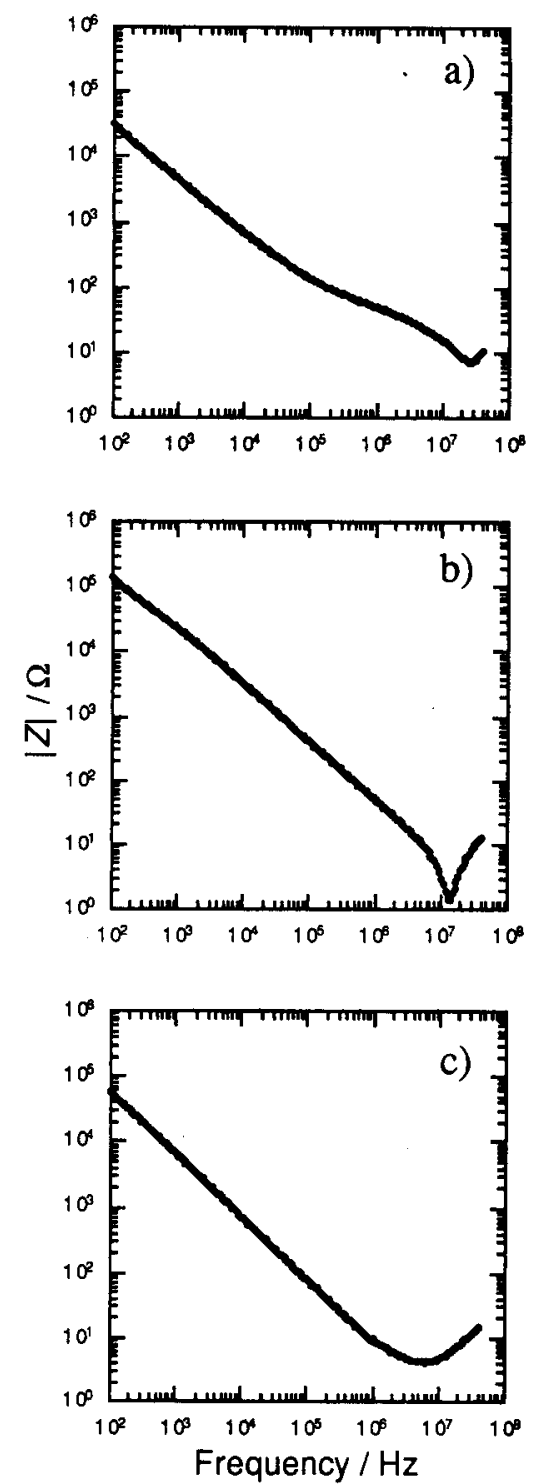

Fig. 10 Bode plots for various aluminum capacitors fabricated by casting the dissolved low molecular weight polyaniline. a) polyaniline, b) polyaniline polymerized with $p$-toluidine and, c) polyaniline polymerized with sulfanilic acid (the molar ratio of $p$-substituted aniline / aniline $=0.001$ ).

に重合したFig. $10 \mathrm{a}$ の場合,インピーダンスは低周波数領域 では直線的に減少しているが, $10^{4} \mathrm{~Hz}$ 付近から上にそれてお り高いESR 值を示した.これはキャスト後のポリアニリン の成膜性が悪く, 均一な導電層が形成されてないことを示唆 している。一方 $p$-トルイジン共存下で重合した Fig. $10 \mathrm{~b} の$ 場合, インピーダンスー周波数曲線は $10^{6} \mathrm{~Hz}$ 付近まで直線的 に減少した後, 共振周波数 $\left(1.3 \times 10^{7} \mathrm{~Hz}\right)$ 付近で鋭く変化 し，最も小さい ESR 值 $(1.4 \Omega)$ を示した，またスルファニ ル酸共存下で重合した Fig. $10 \mathrm{c}$ の場合も ESR 值はやや高い ものの良好であった. 作製したいくつかのコンデンサの静電 容量を测定するとばらつきがあり, 現在キャスト条件の改善 を検討中であるが, 可溶性ポリアニリンを用いる本法の有効 性は確認できた，著者らはポリマーの溶解度が向上したこと により，キャスト成膜後のポリマーの均一性に顕著に影響し たのではないかと考えている，今後，キャスト膜自体の性質 
(電気伝導率, モルフォロジーなど)と得られる電解コンデン サの特性の関係についても調查していきたい。

\section{4 結 論}

重合時にp-トルイジン，スルファニル酸などのパラ置換ア ニリン類をアニリンに対して $1000: 5$ までのモル比で添加す ることにより，低分子量のポリアニリンが得られた。このポ リアニリンはエメラルディン㦈の状態 (ドープ状態)で NMP に対して高い溶解性を示した $\left(250 \mathrm{mg} \mathrm{m} \mathrm{m}^{-1}\right)$ 。この低分子量 ポリアニリンを用いてキャスト法によりアルミ固体電解コン デンサを作製したところ，優れたインピーダンスー周波数特 性が得られた。

\section{謝 辞}

本研究の一部は文部省科学研究費 A (No.10131219) および 基盤研究 C (No.09650744) の援助を受けて実施された。 記し て謝意を表する。

\section{文 献}

1）汇崎 忠, 丹羽信一, 電気化学 (presently Electrochemistry), 58, 794 (1990).

2) 伊佐 功, 渋谷盛興, 島田 博, 丸山敏朗, 電気化学 (presently Electrochemistry)， 58, 604 (1990).

3) Y. Kudoh, S. Tsuchiya, T. Kojima, M. Fukuyama, and S. Yoshimura, Synth. Met., 41-43, 1133 (1991).

4）工藤康夫，表面技術，43，562（1992）.

5）工藤康夫, 福山正雄, 小島利邦, 七井識成, 吉村 進, 電気化 学 (presently Electrochemistry), 61, 240 (1993).

6) L. H. M. Krings, E. E. Havinga, J. J. T. M. Donkers, and F. T. A. Vork, Synth. Met., 54, 453 (1993).

7) Y. Kudoh, M. Fukuyama, and S. Yoshimura, Synth. Met., 66, 157 (1994).

8) A. G. MacDiarmid, J. C. Chiang, M. Halpern, W. S. Haung, S. L. Mu, N. L. D. Somasiri, W. Q. Wu, and S. I. Yaniger, Mol. Cryst. Liq. Cryst., 121, 173 (1985).

9) M. Angelopoulos, A. Ray, and A. G. MacDiarmid, Synth. Met., 21, 21 (1987).

10) J. Tang, X. Jing, B. Wang, and F. Wang, Synth. Met., 24, 231 (1988).

11) R. Z. Jiang and S. J. Dong, Synth. Met., 24, 255 (1988).

12) M. Abe, A. Ohtani, Y. Umemoto, S. Akizuki, M. Ezoe, H. Higuchi, K. Nakamoto, A. Okuno, and Y. Noda, J. Chem. Soc., Chem. Commun., 1989, 1736.

13) Y. Wei, W. W. Focke, G. E. Wnek, A. Ray, and A. G. MacDiarmid, Macromolecules, 23, 758 (1990).

14) M. Leclerc, J. Guay, and L. H. Dao, Macromolecules, 22, 649
(1989).

15) G. Bidan, E. M. Genies, and J. F. Penneau, J. Electroanal. Chem., 271, 59 (1989).

16) L. Wang, X. Jing, and F. Wang, Synth. Met., 29, E363 (1989).

17) Y. Wei, R. Hariharan, and S. A. Patel, Macromolecules, 23, 758 (1990).

18) M. Leclerc, J. Electroanal. Chem., 296, 93 (1990).

19) E. M. Genies and P. Noel, J. Electroanal. Chem., 310, 89 (1991).

20) S. K. Dhawan and D. C. Trivedi, Synth. Met., 60, 60 (1993).

21) P. Snauwaert, R. Lazzaroni, J. Riga, and J. J. Verbist, Synth. Met., 21, 181 (1987).

22) D. Macinnes, Jr. and B. L. Funt, Synth. Met., 25, 235 (1988).

23) J. C. Lacroix, P. Garcia, J. P. Audiere, R. Clementand, and O. Khan, Synth. Met., 44, 117 (1991).

24) M. C. Gupta and S. S. Umare, Macromolecules, 25, 138 (1992).

25) S. K. Dhawan and D. C. Trivedi, Synth. Met., 60, 67 (1993).

26) S. V. Mello, J. H. C. Mattoso, J. R. Santos, Jr., D. Goncalves, R. M. Faria, and O. N. Oliveira, Jr., Electrochimica Acta, 40, 1851 (1995).

27) G. Zotti, N. Comisso, G. D'Aprano, and M. Leclerc, $A d v$. Mater., 4, 749 (1992).

28) T. Ohsaka, T. Okajima, and N. Oyama, J. Electroanal. Chem., 200, 159 (1986).

29) S. K. Monohar, A. G. MacDiarmid, K. R. Cromack, G. M. Ginder, and A. J. Epstein, Synth. Met., 29, E349 (1989).

30) J. Y. Bergeron, J. W. Chevalier, and L. H. Dao, J. Chem. Soc., Chem. Commun., 1990, 180.

31) J. Yue and A. J. Epstein, J. Am. Chem. Soc., 112, 2800 (1990).

32) C. DeArmitt, S. P. Armes, J. Winter, F. A. Uribe, S. Gottesfeld, and C. Mombourquette, Polymer, 34, 158 (1993).

33) S. A. Chen and G. W. Hwang, J. Am. Chem. Soc., 116, 7939 (1994).

34) M. T. Nguyen, P. Kasai, J. L. Miller, and A. F. Diaz, Macromolecules, 27, 3625 (1994).

35) H. S. O. Chan, S. C. Ng, W. S. Sim, T. L. Tan, and B. T. G. Tan, Macromolecules, 25, 6029 (1992).

36) H. S. O. Chan, P. H. H. Ho, S. C. Ng, B .T. G. Tan, and K. L. Tan, J. Am. Chem. Soc., 117, 8517 (1995).

37) D. K. Moon, K. Osakada, T. Maruyama, and T. Yamamoto, Makromol. Chem., 193, 1723 (1992).

38) A. Thyssen, A. Hochfeld, R. Kessel, A. Meyer, and J. W. Schulze, Synth. Met., 29, E357 (1989).

39) S. H. Glarum and J. H. Marshall, J. Electrochem. Soc., 134, 142 (1987).

40) D. E. Stilwell and S. M. Park, J. Electrochem. Soc., 135, 2254 (1988).

41) J. Feng, W. Zhang, A. G. MacDiarmid, and A. J. Epstein, ANTEC, 1373 (1997). 